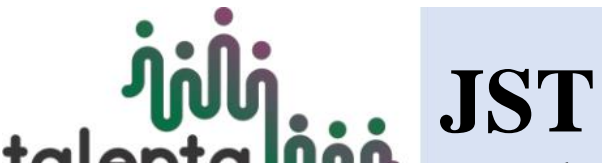 \\ talenta J Journal of Saintech Transfer
}

\section{Utilization of Tofu Rounder Machine in the Small Medium Entrepreneurship (SME) of Tofu Chips in Galang, Deli Serdang Regency, North Sumatra}

\author{
Ridwansyah $^{1)}$, Era Yusraini ${ }^{1) *}$, Terip Karo-Karo'), Zulkifli Lubis ${ }^{2)}$ \\ ${ }^{1)}$ Department of Food Science and Technology, Faculty of Agriculture, Universitas Sumatera Utara \\ ${ }^{2)}$ Department of Food Science and Technology (Master Programme), Faculty of Agriculture, Universitas \\ Sumatera Utara
}

\begin{abstract}
The service team of the Food Science and Technology Study Program, Faculty of Agriculture along with the Community Service Institute of Universitas Sumatera Utara has conducted service activities for partner which was SME of tofu chips in the Hamlet II of Pisang Pala Village, Bangun Purba District, Deli Serdang Regency, North Sumatra Province between May and October in 2018. The partner (named Roemah of Al Fatih), produces raw tofu from soybeans, fried round tofu, and tofu chips. The main problem faced by the partner that started production in 2016 was the difficulty in making spherical of tofu dough as the starting material for tofu chips. So far, the partner has carried out the process of rounding out the dough manually using hand which took a long time. The service team offered a solution by granting a tofu rounder machine from stainless steel using electrical energy. Furthermore, the service team tested the production capacity of the tofu rounder machine and the conventional method (using hand). For the quality of round raw tofu (specific gravity and appearance of the product) and the quality of tofu chips, the team analysed and compared both products which were produced by hand and by machine. The results showed that the use of the tofu rounder machine can increase the capacity of round tofu production significantly, improved the appearance of round tofu products to be denser, and increased the value of preference for the texture of tofu chips produced. The grant of the tofu rounder machine is expected to help the partner to increase the company's profits in the future.
\end{abstract}

Keywords: Production Capacity, Sensory, Texture, Tofu Chips, Round Tofu

Abstrak. Tim pengabdian Program Studi Ilmu dan Teknologi Pangan, Fakultas Pertanian bersama Lembaga Pengabdian kepada Masyarakat Universitas Sumatera Utara telah melakukan kegiatan pengabdian ke UKM keripik tahu di Dusun II Desa Pisang Pala, Kecamatan Bangun Purba, Kabupaten Deli Serdang, Provinsi Sumatera 
Utara dari bulan Mei sampai Oktober 2018. UKM mitra bernama Roemah Tahu Al Fatih yang memproduksi tahu mentah dari kedelai, tahu goreng, dan keripik tahu.Masalah utama yang dihadapi mitra yang mulai berproduksi pada 2016 tersebut adalah kesulitan saat membuat bulatan adonan tahu sebagai bahan awal keripik tahu.Selama ini mitra melakukan proses pembulatan adonan tahu manual menggunakan tangan yang membutuhkan waktu lama. Tim pengabdian menawarkan solusi dengan menghibahkan mesin pembulat tahu dari bahan stainlesstell menggunakan energi listrik.Selanjutnya tim pengabdian menguji kapasitas produksi tahu bulat, mutu produk tahu bulat (berat jenis dan tampilan produk), dan mutu keripik tahu yang diproduksi secara manual dan dengan mesin.Hasil yang diperoleh adalah penggunaan mesin dapat meningkatkan kapasitas produksi tahu bulat dengan sangat tinggi, memperbaiki tampilan produk tahu bulat menjadi lebih padat, dan meningkatkan nilai sensori kesukaan terhadap tekstur keripik tahu yang dihasilkan. Hibah mesin pembulat tahu diharapkan dapat membantu mitra untuk meningkatkan keuntungan perusahaan di masa mendatang.

Kata Kunci: Keripik Tahu, Kapasitas Produksi, Mesin Tahu Bulat, Sensori, Tekstur

Received 22 October 2018 | Revised 10 February 2019 | Accepted 1 April 2019

\section{Introduction}

Chips are generally a type of snack made from ingredients based on carbohydrates which are thinly sliced then fried. Unlike crackers which usually having flour to be added and then steamed and dried before being fried, chips only come from one ingredient which is named on to its products in the market. For instance, banana chips are made from banana; tempeh chips are produced from thinly sliced tempeh then fried. Generally, tofu chips are known produced from thinly formed tofu and then fried. But sometimes the naming of both products; chips and crackers are often been exchanged in the community.

On the whole, the crackers and or chips industries are highly developed in Indonesia and these already have a good value of business efficiency which was above 1, while the tofu chips had the efficiency value up to 1.34 [1]. However, the profit of tofu chips industry still showed a low profitability ratio, namely the ROI (Return on Investment) ratio which was only around $16.82 \%$ [2].

The partner of the Food Science and Technology study program, Faculty of Agriculture's service team in this collaboration work was a small and medium Entrepreneurship which produces tofu chips the owner (SME), Mr. Muhammad Fajri. His business factory is located is in Deli Serdang Regency, namely Bangun Purba 
District, Batu Rata, which is about 50 km from Universitas Sumatera Utara.

This partner's business brand is Roemah Tahu Al Fatih. Mr. Fajri started pioneering his business since the beginning of 2016, when he quitted his formal job. Roemah Tahu Al Fatih produces raw tofu from soybeans, fried round tofu, and tofu chips. Tofu chips are tofu skin products fried in the shape of a half sphere like a helmet (Figure 1). The equipment owned by the partner in running their business can be seen in Table 1. He has two permanent workers in the raw tofu and fried round tofu section and one worker in the tofu chips section.

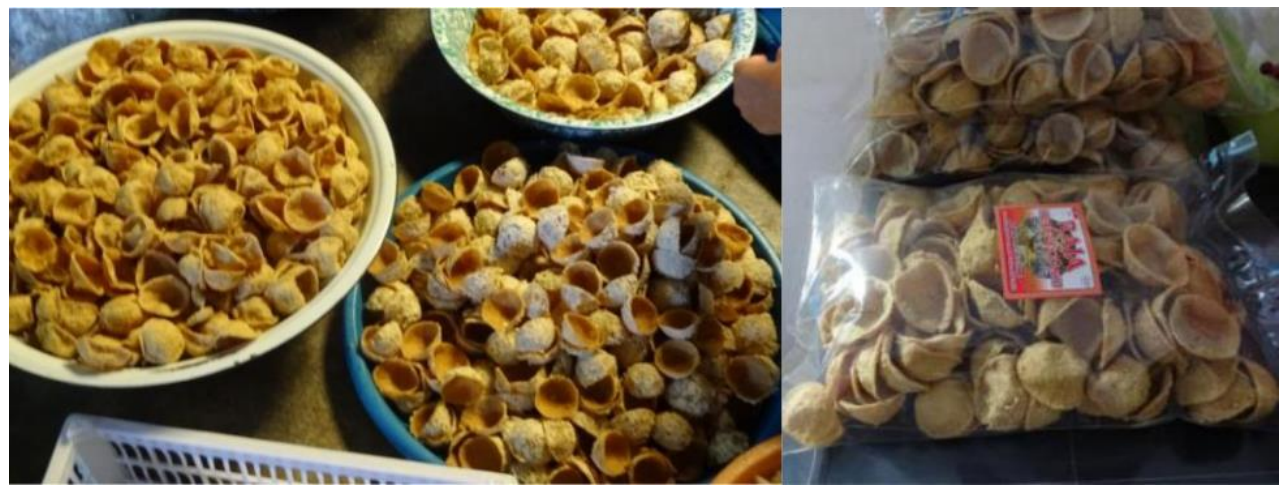

Figure 1. Tofu chips product

Table 1. Equipments which are utilised in Roemah Tahu Al Fatih factory

\begin{tabular}{lll}
\hline No. & \multicolumn{1}{c}{ Equipment } & Total \\
\hline & Processing of raw and fried round tofu & \\
\hline 1. & Wooden mold tofu & 4 \\
2. & Soybean boiling stone stove & 1 \\
3. & Concrete place for squeezing and slicing soybean & 1 \\
& porridge & \\
4. & Soybean grinding machine & 1 \\
5. & Tofu frying stone stove & 1 \\
6. & Plastic storage box & 1 \\
7. & Big skillet & 1 \\
\hline & Processing of tofu chips & 1 \\
\hline 1. & Plastic container for tofu dough & 1 \\
2. & Manual tofu grinder & 2 \\
3. & Burner gas stove & 2 \\
4. & Big skillet and skillet stirrer & 1 \\
5. & Packaging sealer & \\
\hline
\end{tabular}

While running his business, the partner has a gross income from sales of raw tofu and fried round tofu of Rp. 13,000,000 per month (30 working days) with a profit margin of around 20-30\%. Meanwhile, from the tofu chips sales, the partner gets a gross income of Rp. 7,400,000 per month (25 working days) with a profit margin of $20-30 \%$ as well. The profits obtained by the partner are only based on estimation, as the partner still 
utilises simple methods for recording inflow and outflows of funds, and has not running good management and bookkeeping.

The problem faced by the partner to run the business (Figure 2) was that the raw tofu products often not sold out. The partner had problem on about to marketized the products because he had only one worker and one agent. Furthermore, his neighborhoods did not like his raw tofu, and they preferred to buy from another place. Hence, the partner expanded his businesses to fix the issue by started selling out the already fried round tofu. In the year 2017, the partner developed his market by selling tofu chips to extend the shelf life of raw tofu product.

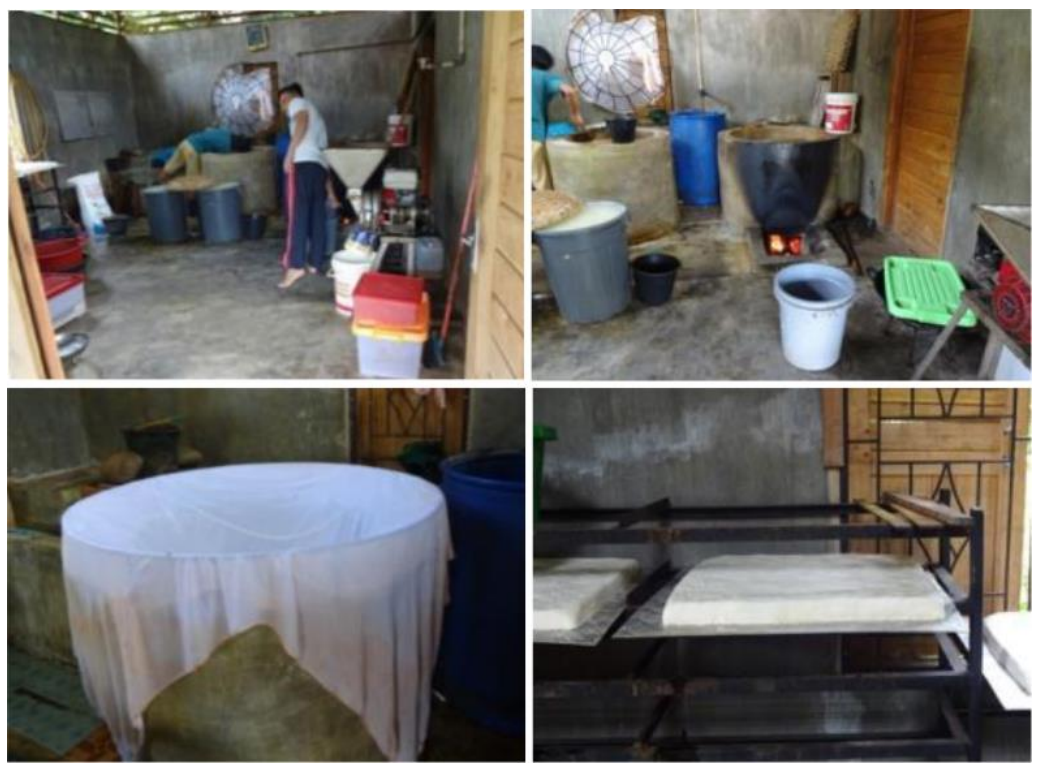

Figure 2. Processing of partner's raw tofu

In the process tofu chips, the partner got difficulties when rounding the crushed tofu spices and flavoring dough. During this time the partner carried out the process of rounding the tofu dough manually by hand as shown in Figure 3, which really took a long time. In addition, the size of the dough was also not similar in size and the density of the dough was not the same between one round tofu and the others. The process of making tofu chips can be seen in Figure 4. 


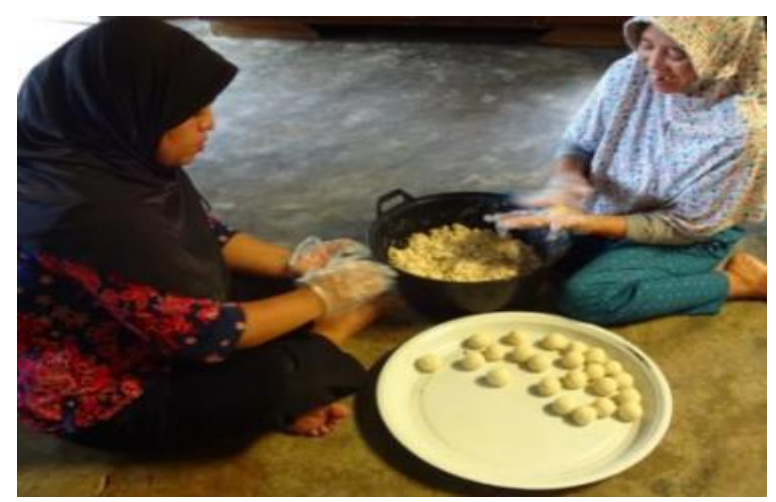

Figure 3. Rounding out the dough tofu by hand

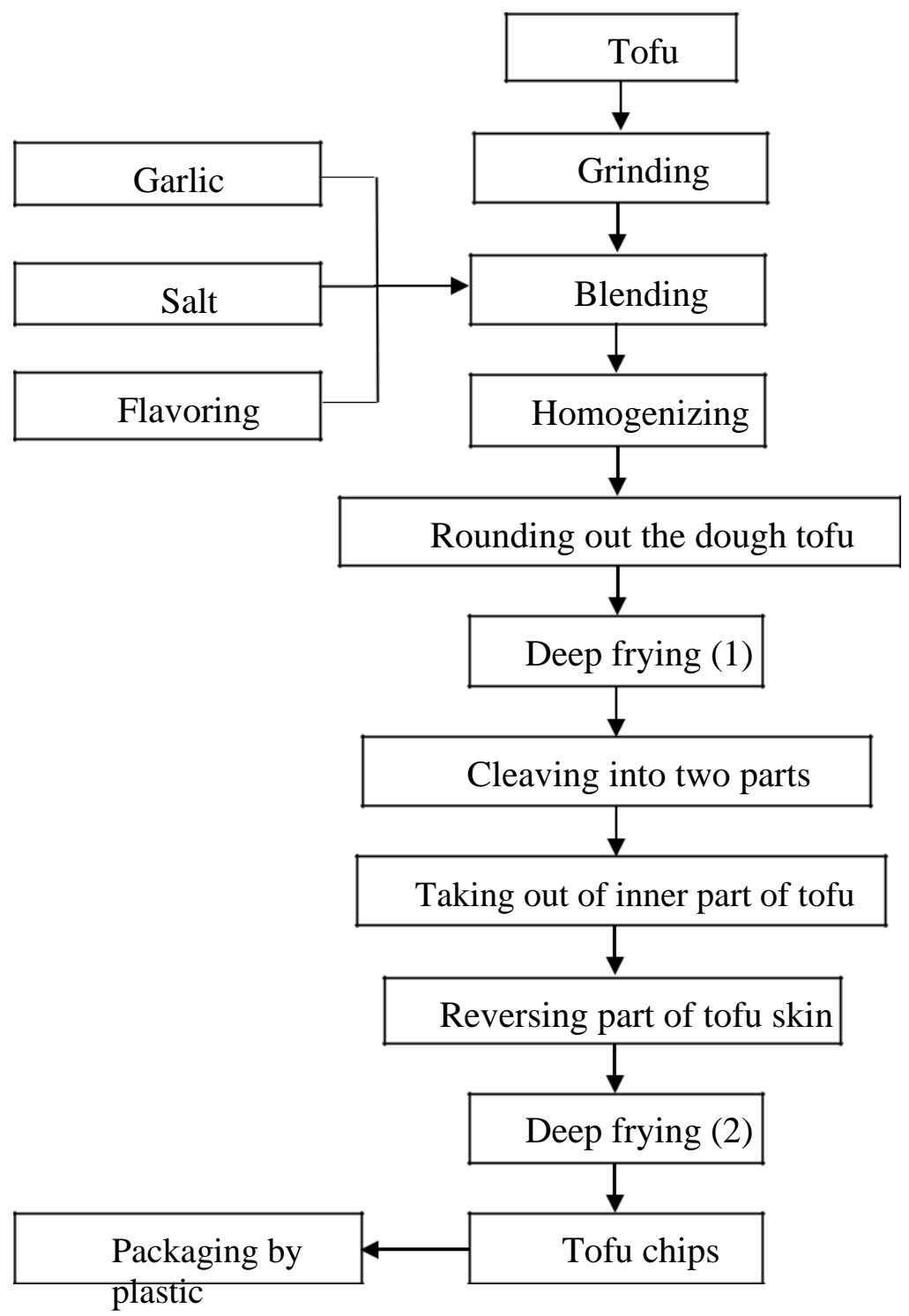

Figure 4. The process of making tofu chips (modification Yusraini [3])

From the situation analysis item that had been explained previously, it could be stated that the top priority of the partner's problem was having obstacles in science and technology aspects of production, i.e. 1) the rounding process of round tofu with hands 
took a long time, 2) the partner did not have a rounder machine 3) the quality of round tofu by manual method was still not uniform, i.e the diameter and density were not consistent.

\section{Methods}

Based on the priority of the partner's problem, then in accordance with the expertise possessed by the service team and the agreement with the partner for the period of implementation of activities that were only 6 (six) months, the solution approach was to solve the production aspect problems, namely:

a. Designing and granting rounder machine.

b. Testing speed and working time to made round tofu by hand and by rounder machine.

c. Quality testing of round tofu which was rounded manually and with a machine.

d. Quality testing of tofu chips from round tofu which was rounded manually and with a machine.

Partner in this service activity was sought to run an active role. This was in accordance with the agreement between the USU service team and the partner. The active participation which would be carried out including:

1. Received of grants for the rounder tofu machine and participating in guarding them and was responsible for making minor repairs that may exist later.

2. Provided facilities for testing the equipment and products that had been agreed upon previously and attended planned meeting actively.

3. Provided equipment and materials which were needed during testing other than those prepared by the service team.

4. Involved directly during the process of testing machines and products.

5. Communicating actively with the service team from USU, if there were things that are needed to be immediately known such as changes in schedules etc.

\section{Results and Discussion}

\subsection{Designing and granting the tofu rounder machine}

At the beginning of the activity, the implementation team at the beginning of the activity coordinated with the partner to design a rounder machine (Figure 5). The design was then assembled by a partner of the service team that assembled the machine according to the order. Furthermore, the service team handed over the tofu rounder machine to the partner in early August 2018 (Figure 6). The specification of rounder machine which assembled and donated to the partner can be found in Table 2 . 

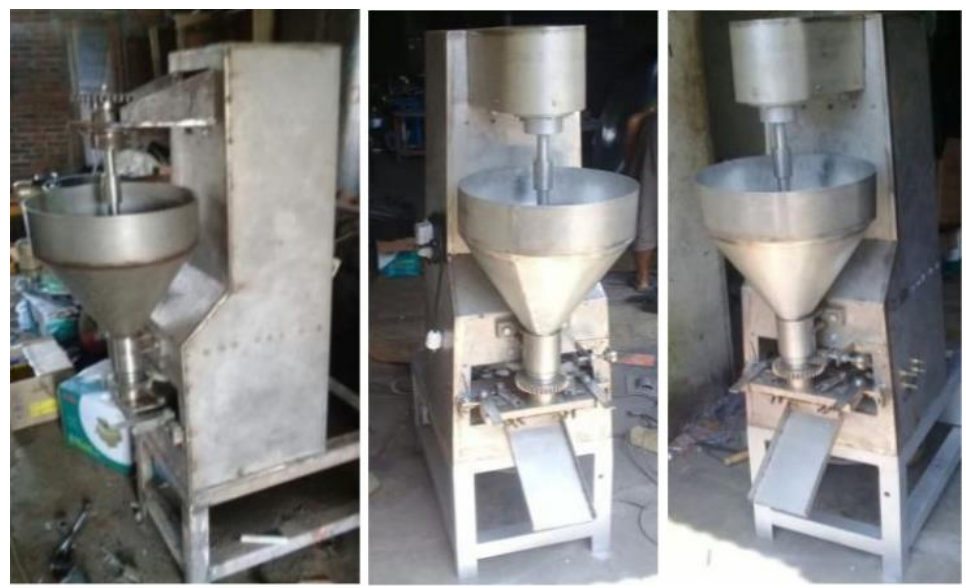

Figure 5. The tofu rounder machine that was granted to the partner

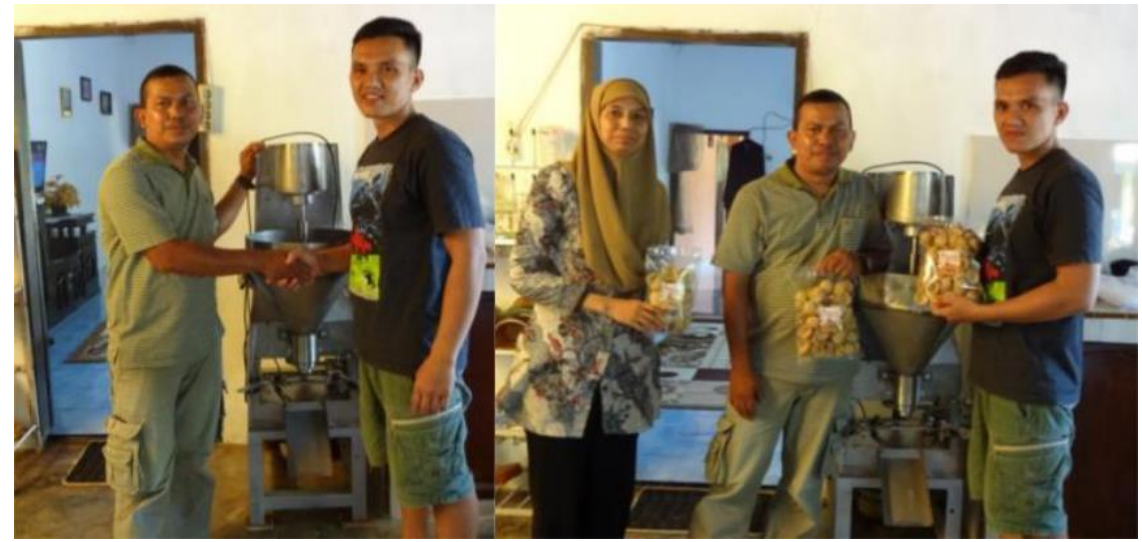

Figure 6. Handovers of the tofu rounder machine granted to the partner

Table 2. Specification of the rounder machine

\begin{tabular}{clc}
\hline No. & \multicolumn{1}{c}{ Description } & Information \\
\hline 1 & General specification & \\
& a. Drive motor & Wipro \\
& b. Maximum power & Electricity; 750 Watt \\
& c. Engine rotation per minutes & 1400 RPM \\
& d. Cooling system & Air \\
\hline 2. & Overall engine unit & \\
& a. Dimension length x width x height & $1400 \times 600 \times 380 \mathrm{~mm}$ \\
& b. machine frame & Stainless steel SS 201 2mm thick \\
\hline 3. & Estimated capacity & 280 round tofu per minute \\
\hline
\end{tabular}

\subsection{Testing the speed and processing time using manual method and the rounder machine}

After the tofu rounder machine was granted, the implementation team then tested the speed and time of processing using the manual method and the rounder machine. Tofu dough that had been crushed and given seasoning was then rounded by manual and using a machine. The manual method was using hands and done by skilled workers. The other way was using the tofu rounder machine. The raw round tofu which made using a 
machine had a less smooth outer surface, so it needed to be smoothed by rounding it back by hand (process with the machine and smoothing by hand).

Table 3., it showed that the use of the rounder machine and the rounder machine with smoothing has a rounding speed and number of round tofu, and produced a higher number of products than the manual. Moreover, the use of the rounder machine required rounding out time in a different processing time which was significantly lower than the manual method. The tofu rounder machine could speed up the rounding process of tofu dough to round tofu at 11 times higher than the manual, and the round tofu which produced by the rounder machine needed no refining to enhance the appearance of tofu chips, and the use of rounder machine followed by hand refinement also accelerated the processing for 1.3 times.

Table 3. Test results for the speed and the processing time for making round tofu

\begin{tabular}{|c|c|c|c|c|}
\hline No. & Description & \multicolumn{2}{|c|}{ Manual*Machine** } & $\begin{array}{l}\text { Machine and smoothing the } \\
\text { outside of the raw round } \\
\text { tofu by hand }\end{array}$ \\
\hline 1. & $\begin{array}{l}\text { Rounding speed } \\
\text { (round tofu/minute) } \\
\text { Rounding time per }\end{array}$ & 2.2 & 34.8 & 4.8 \\
\hline 2. & $\begin{array}{l}\text { one round tofu } \\
\text { (second/ one round } \\
\text { tofu) }\end{array}$ & 26.8 & 1.7 & 12.5 \\
\hline 3. & $\begin{array}{l}\text { Amount of round tofu } \\
\text { (round tofu } / \mathrm{kg} \text { dough) }\end{array}$ & 37.0 & 52.2 & 59.7 \\
\hline 4. & $\begin{array}{l}\text { Processing time } \\
\text { (minutes/kg) }\end{array}$ & 16.6 & 1.5 & 12.5 \\
\hline 5. & $\begin{array}{l}\text { Speed compared to the } \\
\text { manual } \\
\text { method (times) }\end{array}$ & & 11 & 1.3 \\
\hline
\end{tabular}

\subsection{Quality testing of round tofu which was rounded manually and using a rounder machine}

In addition to testing the speed and the processing time, the implementation team also tested the quality of raw round tofu products, namely round tofu by the manual method and by using the machine (the outer surface of which was smoothed by hand again). The tests were carried out on each raw round tofu and fried round tofu.

The results showed that raw round tofu rounded by manual method had a rougher inner surface than those using the rounder machine. This may be due to the rounding process with the rounder machine had a higher condensation ability than the manual one so that it could smooth the surface in slices of the raw round tofu produced (Figure 7). 
Furthermore, the observations were continued by comparing the fried round tofu using the manual method and the rounder machine (the outer surface of the raw round tofu was smoothed by the hand again). Based on Figure 8, it could be seen that fried round tofu rounded using a machine generally had fewer air cavities in the center or had denser surface. This was in accordance with the data obtained on the density of round tofu with the machine which was smaller than round tofu by manual method (Table 4). The result also showed that the volume of machine-shaped round tofu was higher so that it decreased the value of specific gravity from the round tofu.
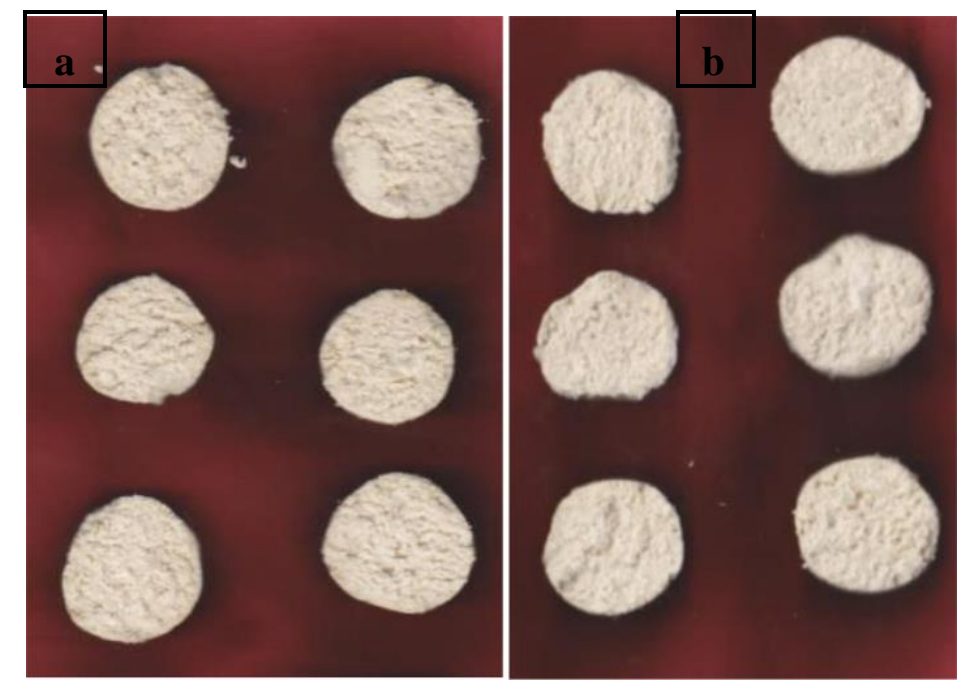

Figure 7. (a) Raw round tofu by the manual method; (b) Raw round tofu by the rounder machine
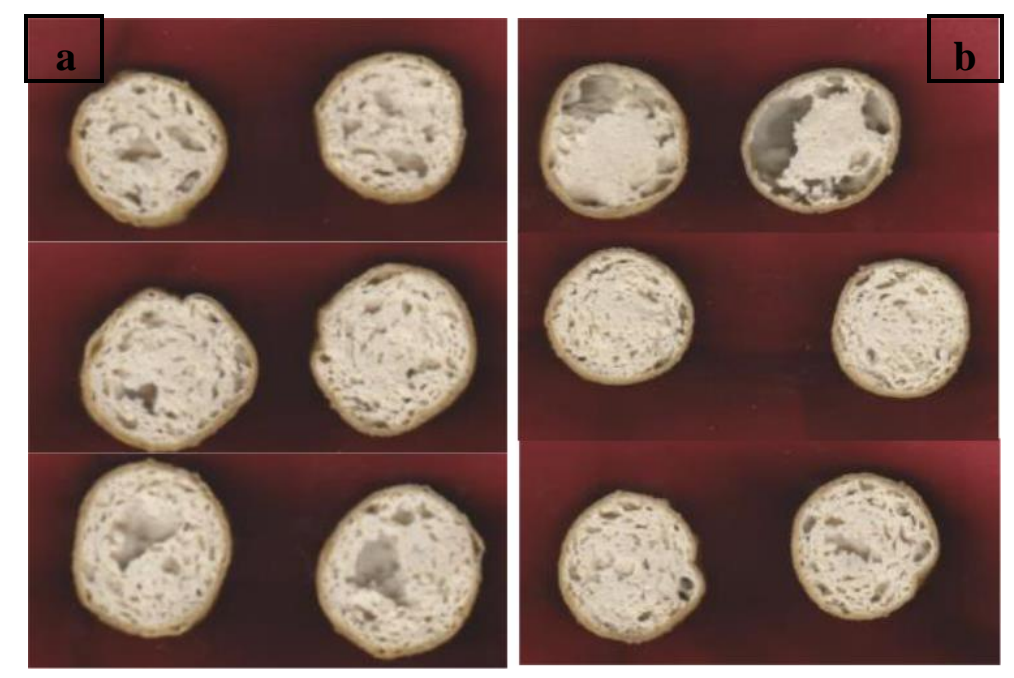

Figure 8. (a) Fried round tofu by the manual method; (b) Fried round tofu by the rounder machine 
Table 4. Physical characteristics of raw round tofu

\begin{tabular}{lcc}
\hline No. Description & Manual & $\begin{array}{c}\text { Machine and smoothing the } \\
\text { outside of the raw round tofu by } \\
\text { hand }\end{array}$ \\
\hline 1. Weight $(\mathrm{g})$ & 27.4 & 22.9 \\
2. Diameter $(\mathrm{cm})$ & 3.52 & 3.34 \\
3. Specific gravity $(\mathrm{g} / \mathrm{ml})$ & 1.04 & 0.98 \\
\hline
\end{tabular}

\subsection{Quality testing of tofu chips which were rounded manually and using a rounder machine}

The partner tofu chips which were rounded manually and with a rounder machine had also been tested for preference in general towards the final level students of the Faculty of Agricultural Product Innovation and Technology, Srinakharinwirot University, Thailand on the end of August 2018 (Figure 9). Almost all students and lecturers liked partner's tofu chips and agreed that its taste was a bit like fish crackers. In addition, the texture of tofu chips was felt fibrous because the sandy texture of the surface of the inner tofu skin also gave the impression of its own unique and preferred texture.

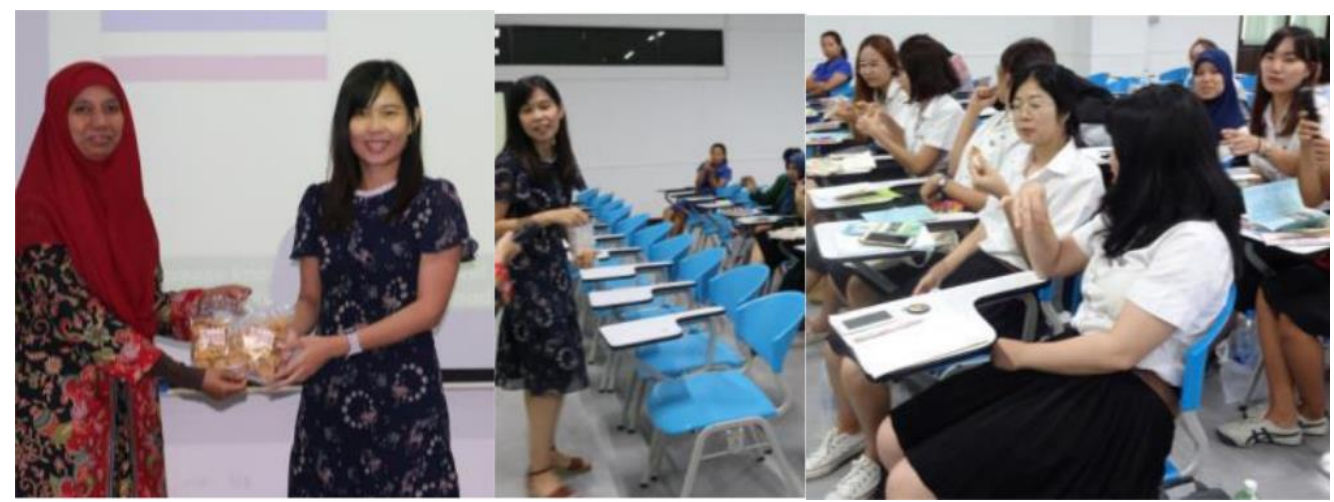

Figure 9. Socialisation of partner products to the Faculty of Agricultural Product Innovation and Technology, Srinakharinwirot University, Ongkharak Thailand

Furthermore, to find out whether the method of rounding round tofu by hand or with a machine influenced the preference of the panelists, the implementation team tested sensory preferences of the products for texture. In addition, the team also conducted a triangular test which aimed to find out whether the product of tofu chips using manual round tofu and round tofu machine had differences. The test results in Table 5 showed that tofu chips from rounder tofu machine were preferred by panelists and significantly different with tofu chips from manual round tofu. The difference was due to differences in the physical characteristics of spherical tofu used which were related to weight, diameter, and specific gravity. 
Table 5. Test results for sensory tofu chips

\begin{tabular}{|c|c|c|}
\hline No. Description & $\begin{array}{l}\text { Tofu chip from raw } \\
\text { round tofu produced } \\
\text { manually }\end{array}$ & $\begin{array}{l}\text { Tofu chip from raw } \\
\text { round tofu produced by } \\
\text { the machine and } \\
\text { smoothing the outside }\end{array}$ \\
\hline 1. Texture* & 5.2 & 5 . \\
\hline $\begin{array}{l}\text { Number of respondents } \\
\text { 2. knowing the different } \\
\text { product (triangular test) }\end{array}$ & 16 & 1 \\
\hline
\end{tabular}

\section{Conclusion}

The implementation of community service activities had been completed and could help solve the problem of the partner, which was to shorten the rounding time of tofu dough as a raw material for tofu chips with granting the tofu rounder machine. The utilization of the tofu rounder machine in Roemah Tahu Al Fatih factory in Bangun Purba Subdistrict, North Sumatra had increased rounding capacity of round tofu which was ultimately expected to increase SME income, in the future. The products of tofu chips produced with round tofu machine also had better characteristics and were preferred by consumers.

\section{Acknowledgments}

This article was supported by internal grant community service programs of Universitas Sumatera Utara (Non PNBP USUgrant, for one year scheme) number 172/UN5.2.3.2.1/PPM/2018, 16th April 2018.

\section{References}

[1] Putri, A.D. 2017. Analysis of tofu crackers agroindustry and rollover "CahayaTidar" in Salaan Village, Mertoyu District and Magelang Regency (Analisis usaha agroindustry kerupuk tahu dan rolase "CahayaTidar" di Desa Salaan Kecamatan Mertoyu dan Kabupaten Magelang).Tesis.UPN Yogyakarta. [Indonesian]

[2] Pratiwi, R.I, and Kalaba, Y. 2014. Profitability analysis of tofu chips business in Sofie's home industry in Palu City (Analisis profitabilitas usaha keripik tahu pada industri rumah tangga Sofie di Kota Palu). J. Agroland 21 (1): 15-21. [Indonesian]

[3] Yusraini, E. 2018.Tofu Chips (KeripikTahu). Ensiklopedia Produk Pangan Indonesia/ Indonesian Food Products Encyclopedia (EPPI)Volume II. Persatuan Ahli Teknologi Pangan Indonesia. Jakarta [Indonesian] 